\title{
Pengaruh Curah Hujan dalam Pembentukan Bunga dan Buah Jambu Bol (Syzygium malaccense)
}

\author{
The Effect of Rainfall in Flowering and Fruiting Initiation of Syzygium malaccense
}

\author{
Kuswandi*, Mega Andini, Sri Hadiati
}

Balai Penelitian Tanaman Buah Tropika, Jl. Raya Solok-Aripan Km 8 Solok, Sumatera Barat 27301

*E-mail Penulis Korespondensi: sutan.mangkuto33@gmail.com

\begin{abstract}
Information about the flowering and fruiting of Syzygium malaccense is required in production planning and plant maintenance. The research objective was to study the effects of rainfall on the formation of flowers and fruits of $S$. malaccense. The research was conducted at the Aripan Experimental Garden, Indonesian Tropical Fruit Research Institute, from August 2015 till February 2016. Observations were made on three flowering periods. This research was a descriptive experiment, the results were shown in the form of the average data and growth charts. Flowering initiation of S. malaccense was stimulated by the length of the dry period. The highest percentage of fallen out flowers occurs during the rainy season. Fruit size increases along with heavy rainfall. Total soluble solids decrease when rainfall is high.
\end{abstract}

Keywords: flowering, rainfall, Syzygium malaccense

\begin{abstract}
ABSTRAK
Informasi tentang pembungaan dan perkembangan buah jambu bol dibutuhkan dalam merencanakan produksi dan perawatan tanaman. Tujuan penelitian ini adalah untuk mempelajari pengaruh curah hujan pada pembentukan bunga dan buah jambu bol. Penelitian telah dilaksanakan di Kebun Percobaan Aripan Balai Penelitian Tanaman Buah Tropika, dari Bulan Agustus 2015 sampai dengan Februari 2016. Pengamatan dilakukan pada tiga periode pembungaan. Kegiatan ini merupakan penelitian deskriptif, hasil penelitian ditampilkan dalam bentuk rataan dan grafik pertumbuhan. Inisiasi pembungaan pada tanaman jambu bol dirangsang oleh lamanya periode kering. Kerontokan bunga tertinggi terjadi selama musim hujan. Nilai total padatan terlarut menurun ketika curah hujan tinggi.
\end{abstract}

Kata Kunci: curah hujan, jambu bol, pembungaan

\section{PENDAHULUAN}

Jambu bol (Syzygium malaccense) merupakan tanaman buah yang berasal dari Semenanjung Malaysia. Di Indonesia tanaman ini dapat ditemukan di pekarangan masyarakat dan sebagian lagi ditanam di kebun. Tanaman ini memiliki banyak manfaat, buahnya dapat berfungsi sebagai antioksidan dan ekstrak daunnya mengandung senyawa anti hiperglikemia yang berperan dalam melawan penyakit diabetes (Arumugam et al., 2014). Buah jambu bol kaya akan vitamin $C$ dan kulit buahnya banyak mengandung antosianin. Tanaman ini merupakan tanaman yang memiliki daya adaptasi luas sehingga menyebar hampir ke seluruh dunia (Keshani et al., 2012; Santos et al., 2016). Setiap tanaman memiliki periode berbunga yang berbeda-beda. Tanaman akan memasuki fase berbunga setelah melewati fase vegetatif. Berlangsungnya fase-fase tersebut sangat dipengaruhi oleh lingkungan sekitar, seperti lama penyinaran, suhu dan kelembaban. Menurut
(Seghieri et al., 2009), proses pembungaan pada tanaman berhubungan dengan berbagai kondisi lingkungan biotik dan abiotik. Studi pembungaan pada tanaman buah-buahan sangat penting untuk dipelajari karena diperlukan dalam pengelolaan kebun, agar jadwal pemupukan, pemangkasan, irigasi, dan manipulasi tanaman dapat dilakukan dengan tepat (Liferdi, 2000).

Pertumbuhan dan perkembangan tanaman dapat dilihat dari pola pertumbuhan tajuk, pertumbuhan akar, pembungaan, dan pembuahan. Faktor lingkungan tanaman akan mempengaruhi aktivitas fisiologi tanaman yang berdampak langsung terhadap fase-fase pertumbuhan dan perkembangan tanaman. Unsur iklim yang mempengaruhi proses fisiologi adalah cekaman abiotik seperti suhu udara, kelembaban udara, curah hujan, kekeringan, panjang hari, dan intensitas penyinaran (Thamrin et al., 2009).

Proses-proses fisiologi yang terjadi pada tanaman jambu bol selanjutnya akan mempengaruhi 
bagian tanaman yang lain sampai mencapai batas pertumbuhan tertentu, misalnya pertumbuhan vegetatif terhenti ketika tanaman memasuki fase berbunga (Liferdi, 2000). Pertumbuhan dan perkembangan tanaman dapat dilihat dari pola pertumbuhan tajuk, pertumbuhan akar, pembungaan, dan pembuahan. Faktor iklim yang mempengaruhi fenomena ini meliputi curah hujan, suhu, penyinaran, dan cekaman kekeringan (Dutta dan Devi, 2015; Kebede dan Isotalo, 2016). Faktor iklim yang sering digunakan pada studi pembungaan pada tanaman buah adalah curah hujan. Pembentukan bunga pada rambutan erat kaitannya dengan lamanya periode kering (Kuswandi, 2014).

Penelitian bertujuan untuk mempelajari pengaruh curah hujan dalam menginisiasi pembentukan bunga dan buah jambu bol.

\section{METODE PENELITIAN}

\section{Waktu dan Tempat}

Penelitian telah dilaksanakan di Kebun Percobaan Aripan, Balai Penelitian Tanaman Buah Tropika, Solok-Sumatera Barat mulai bulan Agustus 2015 sampai Pebruari 2016.

\section{Bahan dan Alat}

Bahan yang digunakan adalah jambu bol koleksi Balai Penelitian Tanaman Buah Tropika berumur sembilan tahun sebanyak 20 tanaman. Alat yang dipergunakan dalam penelitian ini adalah meteran kain, hand refractometer, dan alat tulis.

\section{Prosedur Penelitian}

Penelitian dilaksanakan dengan cara mengumpulkan data pertumbuhan tanaman dan melakukan pengamatan terhadap faktor-faktor yang berhubungan dengan pembungaan tanaman jambu bol. Informasi penting yang diperlukan disamping peubah morfologi adalah tanggal berbunga dan tanggal panen. Pelabelan dilakukan pada saat tanaman mulai berbunga. Pelabelan dimaksudkan untuk menentukan malai yang akan diambil sampel buahnya. Buah dapat dipanen ketika telah memenuhi syarat panen seperti perubahan warna kulit buah dari hijau muda menjadi merah kecoklatan.

Peubah yang diamati terdiri dari: 1) Panjang bunga/buah, pengamatan dilakukan dari pangkal sampai ujung bunga/buah. Pengamatan dilakukan empat hari sekali; 2) Persentase buah jadi, pengamatan dilakukan dengan cara menghitung jumlah bunga per malai dan jumlah buah jadi, kemudian jumlah buah jadi dibandingkan dengan jumlah bunga. Pengamatan dilakukan empat hari sekali; 3) Tanggal bunga mekar, dicatat pada saat bunga pada malai telah mekar sekitar $75 \%$ dari total bunga pada malai; 4) Tanggal panen, dicatat pada saat $75 \%$ buah telah memasuki masak fisiologis, yang ditandai dengan perubahan warna kulit buah dari hijau muda menjadi merah tua; 5) Bobot buah, merupakan rata-rata dari bobot buah per malai; 6) Panjang buah, pengamatan dilakukan dari pangkal sampai ujung buah; 7) Diameter buah, pengamatan dilakukan pada bagian buah terlebar; 8) Total padatan terlarut, pengamatan dilakukan dengan mengambil sedikit daging buah pada bagian pangkal dan ujung buah, kemudian diamati menggunakan hand refractometer; 9) Bobot biji, dilakukan dengan menimbang biji per buah; dan 10) Tebal daging, merupakan rata-rata tebal daging buah hasil pengukuran bagian buah yang tebal dan tipis.

Pengamatan dilakukan selama tiga kali periode berbunga dan panen. Penelitian ini merupakan penelitian deskriptif, data hasil pengamatan ditampilkan dalam bentuk rataan dan grafik pertumbuhan.

\section{HASIL DAN PEMBAHASAN}

\section{Curah hujan dan pembungaan}

Hasil pengamatan terhadap proses pembungaan dan pembuahan pada jambu bol menunjukkan bahwa pada periode pertama jambu bol berbunga pada bulan September 2015 dan panen pada bulan Oktober 2015. Periode kedua berbunga berlangsung pada bulan September 2015 dan panen pada Nopember 2015. Sedangkan, periode ketiga berbunga pada bulan Nopember 2015 dan panen pada bulan Januari 2016 (Gambar 1).

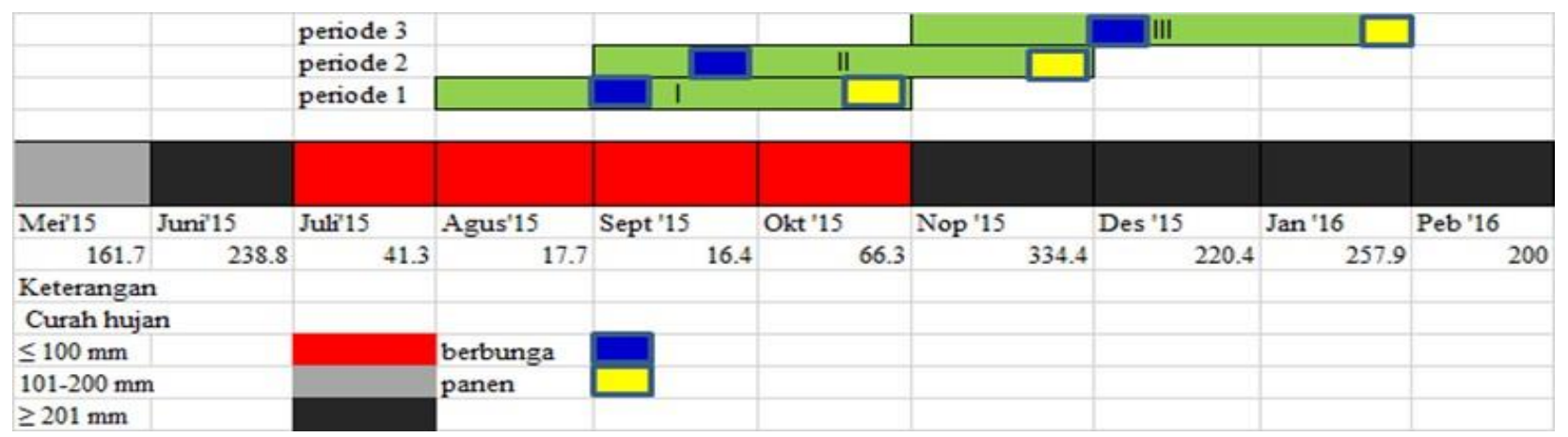

Gambar 1. Hubungan curah hujan dengan inisiasi pembungaan pada jambu bol 
Gambar 1 menunjukkan bahwa sebelum inisiasi pembungaan terjadi musim kemarau selama satu bulan. Kondisi tercekam kekeringan dengan hanya enam hari hujan pada bulan berikutnya merangsang tanaman untuk berbunga. Induksi pembungaan karena cekaman kekeringan kelihatannya juga terjadi pada periode kedua, dengan curah hujan pada bulan sebelum berbunga hanya $17.7 \mathrm{~mm}$ per-bulan. Jumlah hari kering/cerah yang dibutuhkan untuk menginduksi pembungaan pada jambu bol dapat dijelaskan oleh pembungaan periode ketiga. Pada bulan Oktober 2015 (satu bulan sebelum tanaman berbunga) hanya terdapat 4 hari hujan dan sisanya tidak ada hujan. Hal ini dapat menjelaskan bahwa jambu bol ternyata empat hari kering dapat merangsang pembungaan pada jambu bol (Tabel 1).

Tabel 1. Rata-rata curah hujan dan jumlah hari hujan bulan Mei 2015 sampai Januari 2016 di Kebun Percobaan Aripan Balitbu Tropika

\begin{tabular}{clcc}
\hline No & \multicolumn{1}{c}{ Bulan } & $\begin{array}{c}\text { Curah Hujan } \\
(\mathrm{mm})\end{array}$ & $\begin{array}{c}\text { Jumlah Hari } \\
\text { Hujan (hari) }\end{array}$ \\
\hline 1 & Mei 2015 & 161,7 & 14 \\
2 & Juni 2015 & 238,8 & 11 \\
3 & Juli 2015 & 41,3 & 5 \\
4 & Agustus 2015 & 17,7 & 6 \\
5 & September 2015 & 16,4 & 5 \\
6 & Oktober 2015 & 66,3 & 4 \\
8 & Nopember 2015 & 334,4 & 25 \\
7 & Desember 2015 & 220,9 & 19 \\
8 & Januari 2016 & 257,9 & 27 \\
\hline
\end{tabular}

\section{Umur panen jambu bol}

Rata-rata umur panen jambu bol yang ditanam di Kebun Percobaan Aripan Balitbu Tropika ialah 76 hari setelah inisiasi bunga. Panjang bunga terus bertambah tiap periode pengamatan. Penurunan panjang bunga terjadi setelah bunga mekar, yang dilanjutkan dengan rontoknya benang sari, yaitu pada periode pengamatan kedelapan. Setelah buah terbentuk, panjang bunga/buah kembali meningkat (Gambar 2). Umur panen jambu bol dipengaruhi oleh suhu udara. Suhu udara yang tinggi dapat mempercepat panen pada jambu bol. Suhu juga mempengaruhi pembentukan warna merah pada buah (Khandaker et al., 2011; Khandaker dan Boyce, 2016; Uladhar et al., 2015). Umur panen jambu bol koleksi Balitbu Tropika hampir sama pada setiap periode panen. Hal ini diduga disebabkan karena rata-rata suhu maksimum dan minimum di Balitbu Tropika hampir sama dari bulan ke bulan (Tabel 2).

Persentase kerontokan bunga pada jambu bol tertinggi pada periode pertama, sekitar 26 bunga per- tanaman. Kerontokan bunga terendah terdapat pada periode panen ketiga, yaitu sekitar 6 bunga per-pohon (Gambar 3). Tingginya persentase bunga gugur pada periode pertama diduga berhubungan dengan kondisi iklim yang kurang mendukung pada saat itu, yaitu rendahnya intensitas curah hujan dan jumlah hari hujan, sehingga tanaman kekurangan air yang menyebabkan terganggunya proses fisiologi tanaman (Rai et al., 2010).

Pengaruh lingkungan terlihat pada perbedaan ukuran buah pada masing-masing musim panen. Bobot buah tertinggi diperoleh pada panen kedua dengan bobot rata-rata $85,03 \mathrm{~g}$ per-buah. Rerata bobot buah terendah diperoleh pada panen pertama, yaitu 57,67 g. Begitu juga dengan peubah panjang, diameter buah dan bobot biji. Panjang buah terpanjang diperoleh pada panen kedua, yaitu $69,32 \mathrm{~mm}$, dan terpendek pada panen pertama, yaitu 59,60 mm. Diameter buah terlebar juga pada panen kedua, yaitu $53,81 \mathrm{~mm}$, dan terkecil pada panen ketiga, yaitu 43,96 mm (Tabel 3). Bobot biji paling berat diperoleh pada panen kedua, yaitu 9,67 $\mathrm{g}$ dan paling ringan pada panen ketiga, yaitu 4,88 g. Pertambahan ukuran buah yang meliputi bobot, diameter dan panjang buah sangat dipengaruhi oleh ketersediaan air. Curah hujan yang tinggi mampu menginduksi pertumbuhan tunas, jumlah daun, luas permukaan daun, fotosintesis, dan transpirasi, sehingga dapat meningkatkan produksi tanaman secara keseluruhan (Bauweraerts et al., 2014).

Curah hujan yang berhubungan dengan ketersediaan air bagi tanaman memiliki peranan penting dalam peningkatan kandungan nutrisi dan kualitas tanaman. Kekurangan air dapat menyebabkan tanaman mengalami cekaman bahkan kematian. Peningkatan ketersediaan air pada tomat, menyebabkan warna kulit buah menjadi lebih menarik, bobot buah dan total asam meningkat, tetapi menurunkan nilai total padatan terlarut (TPT) (Barbagallo et al., 2012).

Tabel 2. Data rata-rata suhu Balitbu Tropika dari bulan Mei 2019 sampai Januari 2016

\begin{tabular}{lcc}
\hline Bulan (tahun) & $\begin{array}{c}\text { Suhu Maksimum } \\
\left({ }^{\circ} \mathrm{C}\right)\end{array}$ & $\begin{array}{c}\text { Suhu } \\
\text { Minimum }\left({ }^{\circ} \mathrm{C}\right)\end{array}$ \\
\hline Mei 2015 & 30,91 & 22,05 \\
Juni 2015 & 31,1 & 20,95 \\
Juli 2015 & 30,29 & 19,99 \\
Agustus 2015 & 31,13 & 21,34 \\
September 2016 & 31,01 & 21,38 \\
Oktober 2015 & 30,84 & 21,64 \\
Nopember 2015 & 30,37 & 22,05 \\
Desember 2015 & 29,2 & 21,91 \\
Januari 2016 & 28,9 & 22,01 \\
\hline
\end{tabular}




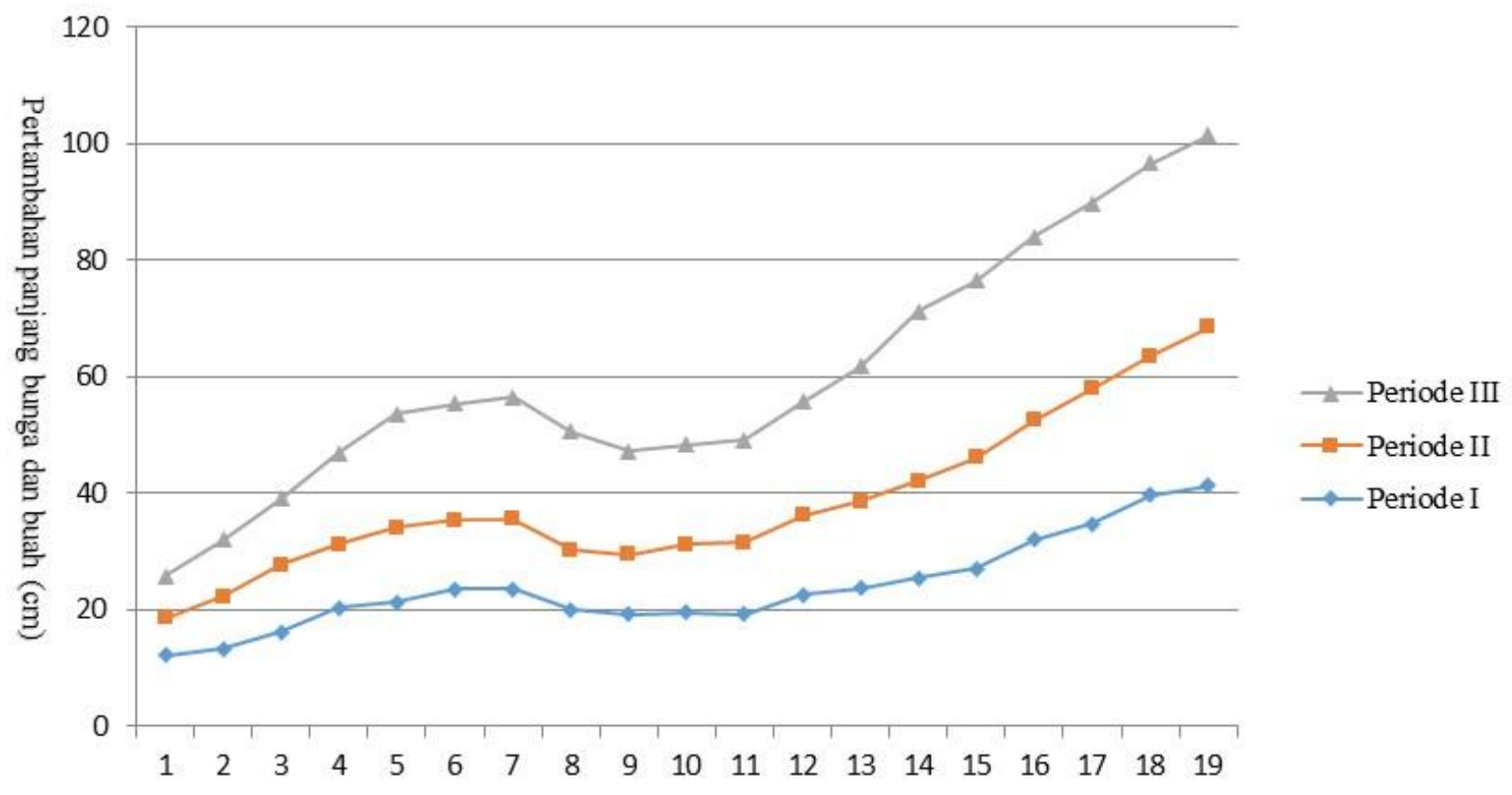

Minggu ke-

Gambar 2. Pertambahan panjang bunga dan buah jambu bol

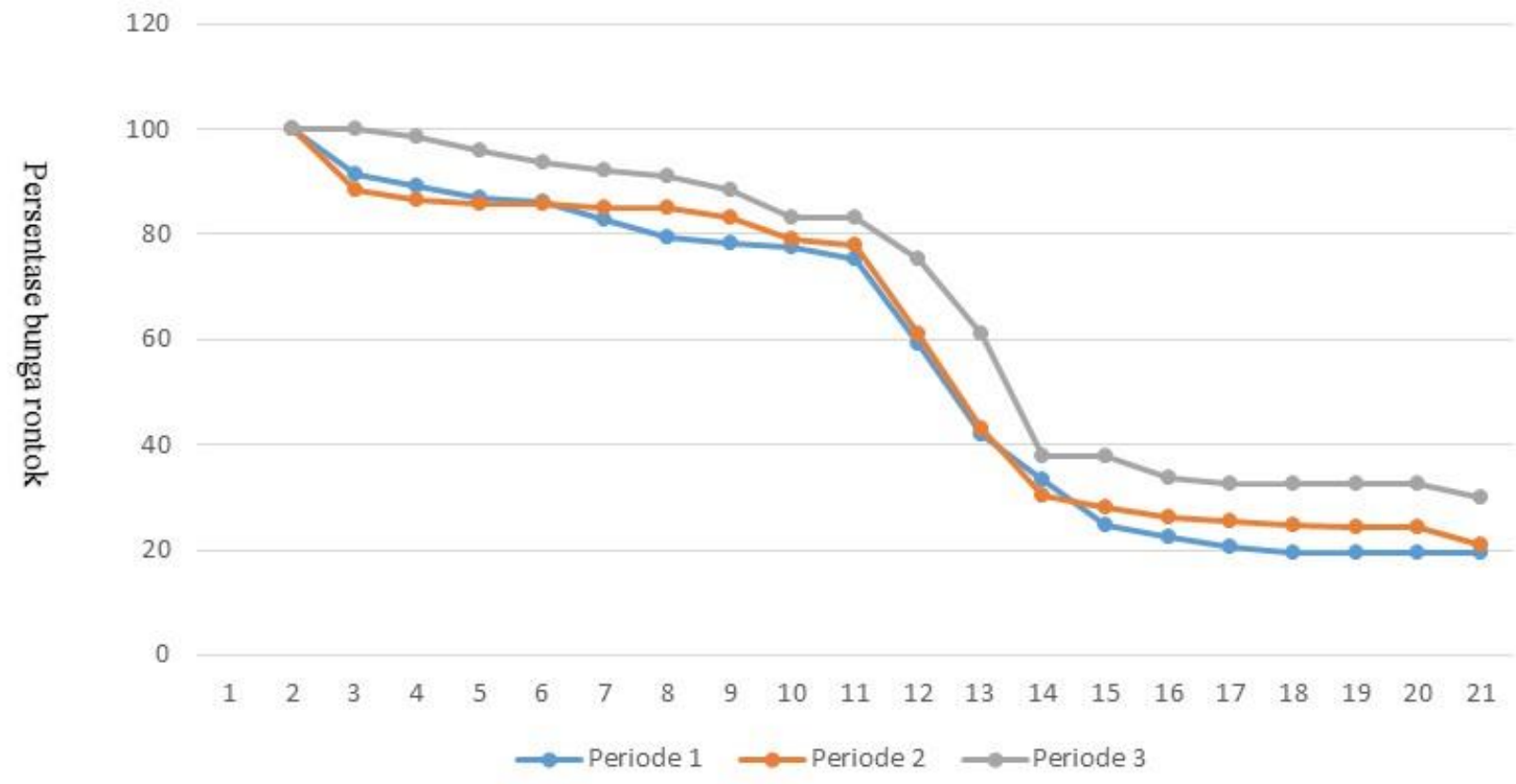

Minggu ke-

Gambar 3. Persentase bunga rontok 
Tabel 3. Rerata bobot buah, panjang buah, diameter buah, TPT, bobot biji dan tebal daging jambu bol.

\begin{tabular}{lccc}
\hline \multicolumn{1}{c}{ Peubah } & Oktober 2015 & Nopember 2015 & Januari 2016 \\
\hline Bobot buah $(\mathrm{g})$ & 57,67 & 85,03 & 64,99 \\
Panjang buah $(\mathrm{mm})$ & 59,6 & 69,32 & 68,41 \\
Diameter buah $(\mathrm{mm})$ & 48,13 & 53,81 & 43,96 \\
Total padatan terlarut TPT ( ${ }^{\circ}$ briks) & 6,14 & 4,69 & 5,75 \\
Bobot biji $(\mathrm{g})$ & 6,85 & 9,67 & 4,88 \\
Tebal daging $(\mathrm{mm})$ & 10,52 & 13,63 & 16 \\
\hline
\end{tabular}

Nilai rata-rata total padatan terlarut (TPT) paling tinggi ditemukan pada panen pertama, yaitu $6,14^{\circ} \mathrm{briks}$, dan yang terendah pada saat panen kedua, yaitu 4,96 ${ }^{\circ}$ briks (Tabel 3). Panen pada periode pertama berlangsung pada akhir musim kemarau, sehingga tanaman kemungkinan mengalami cekaman kekeringan. Sedangkan pada periode panen kedua, panen berlangsung pada saat intensitas hujan sedang tinggi. Menurut beberapa hasil penelitian, cekaman kekeringan dapat meningkatkan nilai TPT pada buah. Hasil penelitian (Yooyongwech et al., 2017) menerangkan bahwa tanaman melon yang tercekam kekeringan kandungan gula yang lebih tinggi dibandingkan tanaman yang mendapatkan pengairan yang cukup.

\section{KESIMPULAN}

Lama periode kering dapat merangsang pembungaan pada jambu bol. Kerontokan bunga tertinggi terjadi pada periode pertama, dan terendah pada periode ketiga. Ukuran buah seperti bobot, panjang, dan diameter buah, serta TPT dipengaruhi oleh curah hujan. Ukuran buah besar ditemukan pada curah hujan tinggi, sedangkan nilai TPT menurun pada curah hujan tinggi.

\section{DAFTAR PUSTAKA}

Arumugam, B., T. Manaharan, C.K. Heng, U.R. Kuppusamy, and U.D. Palanisamy. 2014. Antioxidant and antiglycemic potentials of a standardized extract of Syzygium malaccense. LWT - Food Science and Technology 59: 707712. DOI: 10.1016/j.lwt.2014.06.041.

Barbagallo, R.N, I. Silvestro, and C. Patan. 2012. Yield, physicochemical traits, antioxidant pattern, polyphenol oxidase activity and total visual quality of field-grown processing tomato $\mathrm{cv}$. Brigade as affected by water stress in Mediterranean climate. Journal of Science Food Agriculture 93: 1449-1457. DOI: $10.1002 /$ jsfa.5913

Bauweraerts, I., M. Ameye, T.M. Wertin, M. Anne, R.O. Teskey, and K. Steppe. 2014. Water availability is the decisive factor for the growth of two tree species in the occurrence of consecutive heat waves. Agricultural and Forest Meteorology 189-190: 19-29. DOI: 10.1016/j.agrformet.2014.01.001.
Dutta, G. and A. Devi. 2015. Phenology and population structure of six tree species in tropical forest of Assam, northeast India. Tropical Ecology 56: 393-399.

Kebede, M. and J. Isotalo. 2016. Flowering and fruiting phenology and floral visitation of four native tree species in the remnant moist Afromontane forest of Wondo Genet, South Central Ethiopia. Tropical Ecology 57: 299-311.

Keshani, S., A.L. Chuah, and A.R. Russly. 2012. Effect of temperature and concentration on rheological properties pomelo juice concentrates. International Food Research Journal 19: 553562.

Khandaker, K.M., A.M. Al-Saif, A. Alebidi, A.B.M.S. Hossain, O. Normaniza, and A.N. Boyce. 2011. An evaluation of the nutritional quality evaluation of three cultivars of Syzygium samarangense under Malaysian conditions. African Journal of Agricultural Research 6: 545-552. DOI: 10.5897/AJAR10.923.

Khandaker, M.M. and A.N. Boyce. 2016. Growth, distribution and physiochemical properties of wax apple (Syzygium samarangense): A Review. Australian Journal of Crop Science 10: 1640 1648. DOI: 10.21475/ajcs.2016.10.12.PNE306

Kuswandi. 2014. Analisis Keragaman dan Keragaan Plasma Nutfah Rambutan (Nephelium lappaceum L.) di Indonesia. Tesis. Sekolah Pascasarjana, Institut Pertanian Bogor.

Liferdi, 2000. Studi Fenofisiologi Empat Varietas Rambutan (Nephelium lappaceum L.). Tesis. Sekolah Pascasarjana, Institut Pertanian Bogor.

Rai, I.N., C.G.A. Semarajaya, dan I.W. Wiraatmaja. 2010. Studi fenofisiologi pembungaan salak gula pasir sebagai upaya mengatasi kegagalan fruit-set. Jurnal Hortikultura 20: 216-222.

Santos, P.H., L.H.M. da Silva, A.M. da Cruz Rodrigues, and J.A.R. de Souza. 2016. Influence of temperature, concentration and shear rate on the rheological behavior of malay apple (Syzygium malaccense) juice. Brazilian Journal of Food Technology 19: 1-9. DOI: 10.1590/19816723.0915

Seghieri, J., A. Vescovo, K. Padel, R. Soubie, M. Arjounin, N. Boulain, P. de Rosnay, S. Galle, M. Gosset, A.H. Mouctar, C. Peugeot, and F. Timouk. 2009. Relationships between climate, soil moisture and phenology of the woody cover 
in two sites located along the West African latitudinal gradient. Journal of Hydrology 375: 78-89. DOI: $10.1016 /$ j.jhydrol.2009.01.023

Thamrin, M., S. Susanto, dan E. Santosa. 2009. Efektivitas strangulasi terhadap pembungaan tanaman jeruk pamelo "Cikoneng" (Citrus grandis (L.) Osbeck) pada tingkat beban buah sebelumnya yang berbeda. Jurnal Agronomi Indonesia 37: 40-45. DOI: 10.24831/jai.v37i1.1393

Tuladhar, A, S. Ohtsuka, and N. Nii. 2015. Anatomical study on wax apple (Syzygium samarangense) roots under long-term water-logged conditions. Tropical Agriculture Development 59: 1-6. DOI: 10.11248/jsta.59.1

Yooyongwech, S., T. Samphumphuang, and R. Tisarum, C. Theerawitaya, and S. Cha-Um. 2017. Water-deficit tolerance in sweet potato [Ipomoea batatas (L.) Lam.] by foliar application of paclobutrazol: role of soluble sugar and free proline. Frontiers in Plant Science 8: 1-13. 10.3389/fpls.2017.01400 